\title{
The Injectability of the Advanced Inhibiting Coal Seam and the Effect of Inhibitor Injection
}

\author{
Yansong Zhang \\ College of Mining and Safety \\ Engineering \\ Shandong University of Science and \\ Technology \\ Qingdao, China \\ zys6407@163.com \\ Bo Liu* \\ College of Mining and Safety \\ Engineering \\ Shandong University of Science and \\ Technology \\ Qingdao, China \\ skdliubo@126.com
}

\begin{abstract}
In order to study the injectability of the advanced inhibiting coal seam and the effect of inhibitor injection, taking the 3 upper coal seam in Nantun mine as an example, on the basis of the fact that this coal seam can be injected, the experiment of pressurized water absorption for coal in 9 different solution of inhibitor was carried out. The minimal aperture of pore that allows inhibitor to be injected is deduced according to the pore distribution. The quality of inhibitor that be injected into the coal is calculated. Research shows that the type and concentration of the inhibitor will have an impact on the injection. $\mathrm{MgCl}_{2}$ at a concentration of $25 \%$ is easier to injected into the coal. The minimal aperture of pore that allows $\mathrm{MgCl}_{2}$ to be injected is $0.08 \mu \mathrm{m}$.Per ton of coal can be injected $3.80 \mathrm{~kg}$ of $\mathrm{MgCl}_{2}$. $\mathrm{MgCl}_{2}$ at a concentration of $25 \%$ should be given a priority to be used to achieve the advanced inhibition of this coal seam.
\end{abstract}

Keywords-advanced inhibition, injectability, solution of inhibitor, moisture increase, pore distribution, minimal aperture of pore

\section{INTRODUCTION}

The problem of coal spontaneous combustion in China is serious. One of the fire extinguishing technique at home and abroad is preventing coal spontaneous combustion by using inhibitors[1]. Advanced inhibition is that solution of inhibitor is injected into coal seam by drilling before being mining of easily spontaneous combustion coal seam to infiltrate the pore of coal, which can prolong the cycle of spontaneous combustion and solve the problem fundamentally[2]. The key to achieve a good effect for advanced inhibition is selecting appropriate inhibitors to inject into the pore of coal effectively.

Scholars at home and abroad have been studying on the experiments of inhibition effects[3-6] and the selection of inhibitors[7,8] by taking coal particles as the test object for many years so that the influence of pore distribution of crude coal on the injection effect of inhibitor is not taken into account. So the lack of basis for the amount of inhibitors may cause the inconsistent between the test results and the actual application effects. When it comes to the injectability of slurry[9-11], Chen Kai and others[12] have studied the injectability of chemical grout in weak cementation porous media by taking 6 penetration models with differentpermeability. Li Xiaolong and others[13] have studied the injection effects of new sol resin grout in pore and micro fissures-rock by the field test. Ruan Wenjun and others[14] have studied the injectability of chemical grout by using the plastic strength and injectability period. The above studies mainly analyzed the injection effects of grout from a macro perspective but do not research the relation between the pore distribution and injection effects of grout from a micro perspective.

Therefore, the author selects $\mathrm{MgCl}_{2}, \mathrm{NH}_{4} \mathrm{H}_{2} \mathrm{PO}_{4}$ and water glass to prepare solution of inhibitor at a concentration of $15 \%, 25 \%$ and $35 \%$ respectively by taking the 3 upper coal seam in Nantun mine as an example. And the experiment of pressurized water absorption for coal in 9 different solution of inhibitor is carried out. Combining the influence of the pore distribution on injection effects, the best inhibitor is selected, which has practical significance on guiding advanced inhibition of coal seam.

\section{COAL SEAM CharaCteristics AND THE DETERMINATION} OF INJECTABILITY

\section{A. Coal Seam Characteristics}

The coal seam characteristics are shown in Table 1 by taking the 3 upper coal seam in Nantun mine as a test object.

TABLE I. THE 3 UPPER COAL SEAM CHARACTERISTICS IN NANTUN MINE

\begin{tabular}{clllll}
\hline $\begin{array}{c}\text { Seam } \\
\text { depth/m }\end{array}$ & $\begin{array}{l}\text { Coal } \\
\text { seam } \\
\text { structure }\end{array}$ & $\begin{array}{l}\text { Coal } \\
\text { mark }\end{array}$ & $\begin{array}{l}\text { Coal seam } \\
\text { thickness } m\end{array}$ & $\begin{array}{l}\text { Coal } \\
\text { seam dip } \\
\text { angle/ } \\
\left({ }^{\circ}\right)\end{array}$ & $\begin{array}{c}\text { Stable } \\
\text { degree }\end{array}$ \\
\hline 325.6 & $\begin{array}{l}\text { Single } \\
\text { coal } \\
\text { seam }\end{array}$ & Gas coal & 6.2 & 5.0 & stable \\
\hline
\end{tabular}

\section{B. Experiments on Injectability of Coal Seam}

The experiment on the injectability of the 3 upper coal seam in Nantun mine is carried out including initial moisture, total porosity, natural saturated water absorption and 
firmness coefficient tests[15]. The coal total porosity (n) can be tested by the density method and calculated by the following formula.

$$
\begin{aligned}
& n=\frac{V_{t}-V_{s}}{V_{t}} \times 100 \\
& V_{t}=m / \rho_{A} \\
& V_{s}=m / \rho_{T} \\
& n=\left(1-\frac{\rho_{A}}{\rho_{T}}\right) \times 100
\end{aligned}
$$

In the above formula, $\mathrm{n}$ is total porosity of coal in $\%, V_{t}$ is the total volume of coal in $\mathrm{mL}, \mathrm{Vs}$ is the ture volume of coal in $\mathrm{mL}, \mathrm{m}$ is the coal quality in $\mathrm{g}, \rho_{A}$ is the apparent relative density of coal in $\mathrm{mg} / \mathrm{cm}^{3}$ and $\rho_{T}$ is the true relative density of coal in $\mathrm{mg} / \mathrm{cm}^{3}$.

Based on the above tests, the performance parameters of coal seam inhibitors are shown in Table 2 .

TABLE II. THE PARAMETERS OF COAL SEAM INJECTABILITY

\begin{tabular}{cccccc}
\hline Items & $\begin{array}{c}\text { Initial } \\
\text { moisture } \\
M_{t} / \%\end{array}$ & $\begin{array}{c}\text { Porosity } \\
n / \%\end{array}$ & $\begin{array}{c}\text { Natural } \\
\text { saturated } \\
\text { water } \\
\text { absorption } \\
\varphi / \%\end{array}$ & $\begin{array}{c}\text { Firmness } \\
\text { coefficients } \\
f\end{array}$ & Conclusion \\
\hline $\begin{array}{c}\text { Evaluation } \\
\text { results } \\
\begin{array}{c}\text { Measured } \\
\text { results }\end{array}\end{array}$ & $\leq 4.0$ & $\geq 4.0$ & $\geq 1.0$ & $\geq 0.4$ & injection \\
\hline
\end{tabular}

As is shown in Table 2, the 3 upper coal seam in Nantun mine is water injection coal seam because it satisfies $M_{t} \leqslant$ $4.0, n \geqslant 4.0, \varphi \geqslant 1.0$ and $f \geqslant 0.4$ at the same time. Therefore, the coal seam meets the basic conditions for advanced inhibition.

\section{THE EXPERIMENT OF PRESSURIZED WATER ABSORPTION}

\section{A. The preparation and treatment of coal samples}

The fresh coal samples in the 3 upper coal seam are collected and sealed. After removing the surface oxide layer in the laboratory, the coal sample is cut into $50 \mathrm{~mm} \times 50 \mathrm{~mm} \times 50 \mathrm{~mm}$ cubes and then weighed by electronic balance, which is marked as $\mathrm{M}$.

\section{B. The preparation of solution of inhibitor}

The author selects $\mathrm{MgCl}_{2}, \mathrm{NH}_{4} \mathrm{H}_{2} \mathrm{PO}_{4}$ and water glass to prepare solution of inhibitor at a concentration of $15 \%$, $25 \%$ and $35 \%$ respectively. The solution is stirred with a glass rod. D2010W electric agitator that the rotation speed is $800 \mathrm{r} / \mathrm{min}$ is used for $3 \mathrm{~min}$ after there is no obvious precipitate so as to make the solution as uniform as possible.

\section{The test equipment and procedures}

A self-designed pressurized water absorption device is used for the test. As shown in Figure 2, it includes highpressure tank, steel wire mesh, pressure gauge, fluid input valve, regulator, pressure pump, blow-down valve and so on. During the test, the specimens are placed on the wire mesh of high-pressure tank in turn. Then the tank is closed, and the pressure pump, the regulator and the fluid input valve are opened in turn. The compression pressure is set to $7 \mathrm{MPa}$, and the cumulative pressure time is $3 \mathrm{~d}$. Open the blow-down valve to discharge the exhaust waste after the pressurized water absorption. After cleaning the surface solution with a wet towel, the specimens are weighed by electronic balance, which is marked as $\mathbf{M}_{1}$. Calculate the moisture increase of every specimen and take the average. The above steps are repeated to test the moisture increase of the coal samples in the 6 kinds of inhibitors, and the moisture increase can be calculated by the following formula.

$$
\delta=\left(\frac{M_{1}}{M}-1\right) \times 100
$$

In the above formula, $\delta$ is moisture increase of the specimen in $\%, \mathrm{M}$ is the original weight of the specimen in $\mathrm{g}, \mathrm{M}_{1}$ is the weight of the specimen after absorbing water in $\mathrm{g}$.

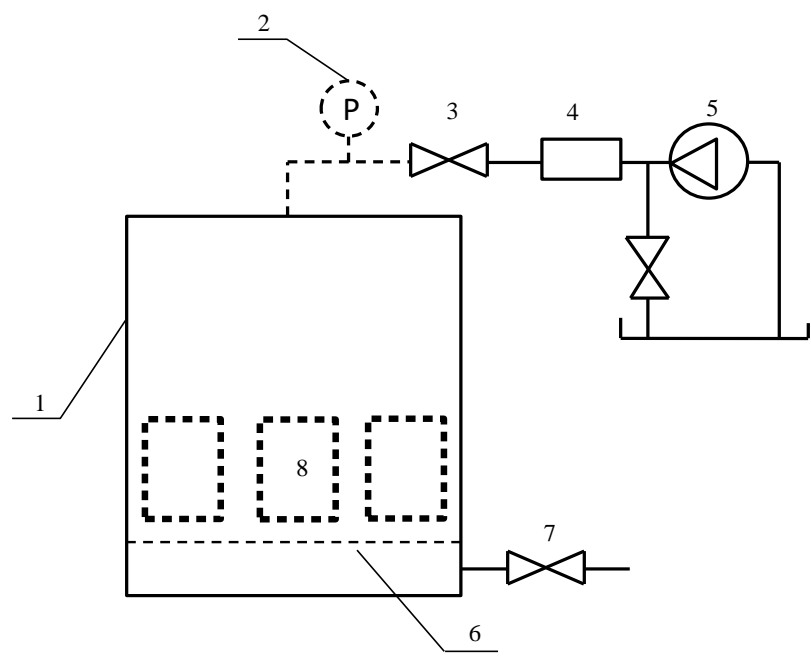

1. High-pressure tank; 2. Pressure gauge; 3 . Fluid input valve; 4. Regulator; 5. Pressure pump; 6. Steel wire mesh; 7. Blow-down valve; 8. Coal specimen;

Fig. 1. The equipment of pressurized water absorption

\begin{tabular}{|c|c|c|c|c|c|c|}
\hline $\begin{array}{c}\text { Types } \\
\text { of } \\
\text { inhibitor } \\
\mathrm{s}\end{array}$ & $\begin{array}{c}\text { Conce } \\
\text { ntratio } \\
\text { ns }\end{array}$ & $\begin{array}{c}\text { The } \\
\text { number } \\
\text { of } \\
\text { specime } \\
\text { ns }\end{array}$ & $\begin{array}{l}\text { Origin } \\
\text { al } \\
\text { weight } \\
\mathrm{s} M / \mathrm{g}\end{array}$ & $\begin{array}{c}\text { Weights } \\
\text { after } \\
\text { absorbi } \\
\text { ng } \\
\text { water } \\
M_{1} / g\end{array}$ & $\begin{array}{c}\text { Moistu } \\
\text { re } \\
\text { increas } \\
\text { e } \delta / \%\end{array}$ & $\begin{array}{c}\text { The } \\
\text { averag } \\
\text { e } \\
\text { moistu } \\
\text { re } \\
\text { increas } \\
\mathrm{e} \text { 错 } \\
\text { 误!未 } \\
\text { 找到 } \\
\text { 引用 } \\
\text { 源。 } \\
\text { /\% }\end{array}$ \\
\hline \multirow{9}{*}{$\mathrm{MgCl}_{2}$} & \multirow{3}{*}{$15 \%$} & $A_{15-1}$ & 170.04 & 173.08 & 1.79 & \multirow{4}{*}{1.73} \\
\hline & & $A_{15-2}$ & 171.13 & 174.23 & 1.81 & \\
\hline & & $\mathrm{A}_{15-3}$ & 166.35 & 168.99 & 1.59 & \\
\hline & \multirow{3}{*}{$25 \%$} & $\mathrm{~A}_{25-1}$ & 177.51 & 179.94 & 1.37 & \\
\hline & & $\mathrm{A}_{25-2}$ & 178.73 & 181.52 & 1.56 & \multirow[t]{2}{*}{1.52} \\
\hline & & $\mathrm{A}_{25-3}$ & 166.59 & 169.31 & 1.63 & \\
\hline & \multirow{3}{*}{$35 \%$} & $\mathrm{~A}_{35-1}$ & 183.03 & 184.92 & 1.03 & \multirow{3}{*}{1.14} \\
\hline & & $\mathrm{A}_{35-2}$ & 183.77 & 186.21 & 1.33 & \\
\hline & & $\mathrm{A}_{35-3}$ & 161.41 & 163.12 & 1.06 & \\
\hline
\end{tabular}

\section{The test results and analysis}

The test results of pressurized water absorption are shown in Table 3.

TABLE III. THE TEST RESULTS OF PRESSURIZED WATER ABSORPTION 


\begin{tabular}{ccccccc}
\hline & & $\mathrm{B}_{15-1}$ & 174.87 & 177.65 & 1.59 & \\
& $15 \%$ & $\mathrm{~B}_{15-2}$ & 177.50 & 180.46 & 1.67 & 1.71 \\
$\mathrm{NH}_{4} \mathrm{H}_{2} \mathrm{P}$ & & $\mathrm{B}_{15-3}$ & 176.63 & 179.93 & 1.87 & \\
$\mathrm{O}_{4}$ & $25 \%$ & $\mathrm{~B}_{25-1}$ & 170.13 & 172.07 & 1.14 & \\
& & $\mathrm{~B}_{25-2}$ & 171.99 & 174.45 & 1.43 & 1.36 \\
& & $\mathrm{~B}_{25-3}$ & 178.38 & 181.07 & 1.51 & \\
& & $\mathrm{~B}_{35-1}$ & 173.86 & 175.23 & 0.79 & \\
& & $\mathrm{~B}_{35-2}$ & 181.30 & 183.13 & 1.01 & 0.93 \\
& & $\mathrm{~B}_{35-3}$ & 176.27 & 178.02 & 0.99 & \\
& & $\mathrm{C}_{15-1}$ & 169.41 & 171.66 & 1.33 & \\
Water & & & & \\
glass & & $\mathrm{C}_{15-2}$ & 171.43 & 174.00 & 1.50 & 1.58 \\
& & $\mathrm{C}_{15-3}$ & 175.56 & 178.91 & 1.91 & \\
& & $\mathrm{C}_{25-1}$ & 169.24 & 171.08 & 1.09 & \\
& & $\mathrm{C}_{25-2}$ & 170.86 & 172.64 & 1.04 & 1.16 \\
& $\mathrm{C}_{25-3}$ & 177.71 & 180.11 & 1.35 & \\
& & $\mathrm{C}_{35-1}$ & 165.19 & 165.90 & 0.43 & \multirow{2}{*}{$35 \%$} \\
& & $\mathrm{C}_{35-2}$ & 181.66 & 182.95 & 0.71 & 0.62 \\
\hline & $\mathrm{C}_{35-3}$ & 182.42 & 183.73 & 0.72 & \\
\hline
\end{tabular}

As is shown in Table 3, the average moisture increase of the specimen after pressurized water absorption of inhibitors varies from the variety and concentration of the inhibitors. For different inhibitors, the average moisture increase of the specimen is $\mathrm{MgCl}_{2}>\mathrm{NH}_{4} \mathrm{H}_{2} \mathrm{PO}_{4}>$ water glass. For same inhibitors, the average moisture increase of the specimen declines with the increasing of solution concentration. When the concentration of the inhibitor is $15 \%$, the difference of the average moisture increase in the 3 kinds of inhibitors is not obvious, which is close to the natural saturated water absorption of the coal. When the concentration of the inhibitor is $35 \%$, the average moisture increase in the $\mathrm{NH}_{4} \mathrm{H}_{2} \mathrm{PO}_{4}$ and the water glass is obviously smaller that is only half of that in the inhibitor that concentration is $15 \%$.

\section{THE Minimal APERTURE OF PORE THAT INHIBITORS ARE INJECTED INTO COAL}

In the pressurized water absorption test of coal, the pore that allows the injection of inhibitors is called the injection pore, which belongs to a part of the linked porosity. The linked porosity rate can be tested by mercury intrusion method. In fact, the pore only includes those that aperture is more than $0.0078 \mu \mathrm{m}$ and is linked with each other. The linked porosity and the test results of pore distribution are shown in Table 4.

TABLE IV. THE LINKED POROSITY AND THE TEST RESULTS OF PORE DISTRIBUTION

\begin{tabular}{ccccccc}
\hline \multirow{2}{*}{$\begin{array}{c}\text { The linked porosity } \\
1 \%\end{array}$} & \multicolumn{5}{c}{ Pore distribution } \\
\cline { 2 - 6 } & $0.01 \mu \mathrm{m}$ & $0.1 \mu \mathrm{m}$ & $1.0 \mu \mathrm{m}$ & $\begin{array}{c}0.10 \mu \mathrm{m} \\
0\end{array}$ & $>10 \mu \mathrm{m}$ \\
\hline 4.31 & 26 & 29 & 17 & 18 & 10 \\
\hline
\end{tabular}

If the injection porosity and the linked porosity meet the following formula.

$$
n_{k}=w n_{g}
$$

In the formula, $n_{k}$ is the injection porosity in $\% ; n_{g}$ is the linked porosity in $\% ; w$ is the percentage of injection porosity of linked porosity in coal in $\%$.

Assuming that the injection porosity can all be filled with a inhibitor, the average moisture increase of the sample in the inhibitor can be expressed as following.

$$
\bar{\delta}=\rho_{A}^{-1} n_{g} w
$$

In the formula, 错误!未找到引用源。is the average moisture increase of the sample, $\rho_{A}$ is apparent relative density of coal in $\mathrm{mg} / \mathrm{cm}^{3}$.

Transform the formula (7):

$$
w=\rho_{A} n_{g}^{-1} \bar{\delta}
$$

According to the linked porosity of coal and the results of pressurized water absorption test, the percentage of injection porosity of linked porosity of the coal in different inhibitors can be calculated $(w)$, then compare with the distribution of linked pore in Table 4, using the interpolation method, the minimum pore diameter $\left(d_{\min }\right)$ for the different resistance liquid to be injected by coal can be calculated. The calculation results are shown in Table 5.

\begin{tabular}{|c|c|c|c|c|c|c|c|c|c|}
\hline \multirow{2}{*}{ Items } & \multicolumn{3}{|c|}{$\mathrm{MgCl}_{2}$} & \multicolumn{3}{|c|}{$\mathrm{NH}_{4} \mathrm{H}_{2} \mathrm{PO}_{4}$} & \multicolumn{3}{|c|}{ Water glass } \\
\hline & $15 \%$ & $25 \%$ & $35 \%$ & $15 \%$ & $25 \%$ & $35 \%$ & $15 \%$ & $25 \%$ & $35 \%$ \\
\hline$w / \%$ & 56.2 & 49.4 & 37.0 & 55.5 & 44.2 & 30.2 & 51.3 & 37.7 & 20.1 \\
\hline$d_{\min } / \mu \mathrm{m}$ & 0.06 & 0.08 & 0.47 & 0.06 & 0.10 & 0.87 & 0.08 & 0.43 & 4.4 \\
\hline
\end{tabular}

TABLE V. THE MINIMAL APERTURE OF PORE THAT INHIBITORS ARE INJECTED INTO COAL

As can be seen from Table 5, the minimal aperture of pore that inhibitors are injected into coal is closely related to the type and concentration of the inhibitor. The minimum pore size of $\mathrm{MgCl}_{2}$ solution that is allowed to enter the coal at various concentrations was lower than that of $\mathrm{NH}_{4} \mathrm{H}_{2} \mathrm{PO}_{4}$ and water glass. The greater the concentration of the inhibitor solution is, the smaller the percentage of injectable porosity in coal is. The bigger the pore size of the inhibitor solution is, the harder it is to inject. When the concentration of the inhibitor solution is increased from $15 \%$ to $25 \%$, the minimum pore size allowed to infiltrate into $\mathrm{MgCl}_{2}$ and $\mathrm{NH}_{4} \mathrm{H}_{2} \mathrm{PO}_{4}$ remains nearly unchanged, both between 0.06 and $0.10 \mu \mathrm{m}$, which is easier to inject. When the concentration of the inhibitor solution turns into $35 \%$, the minimum size allowed to infiltrate into $\mathrm{NH}_{4} \mathrm{H}_{2} \mathrm{PO}_{4}$ and water glass becomes respectively $0.87 \mu \mathrm{m}$ and $4.4 \mu \mathrm{m}$.This shows the inhibitor solution is difficult to be injected into coal.

\section{The AMOUnT OF COAL InHIBITORS}

In the process of advanced inhibition, the actual amount of resistance which can be injected into the tons of coal pores, is known as tons of coal resistance agent injection, it can be calculated by using the following formula:

$$
Q=\bar{\delta} C \times 10^{3}
$$

In the formula, $Q$ represents the amount of tons of resistance agent injection in $\mathrm{kg}, C$ is the concentration of resistance solution in $\%$.

The calculation results of the three kinds of inhibitors of tons of coal resistance agent injection are shown in Figure 2.

It can be seen from Figure 2 that the dosage of $\mathrm{MgCl}_{2}$ is an increasing one, and the dosage of one ton of inhibitor outnumbers that of $\mathrm{NH}_{4} \mathrm{H}_{2} \mathrm{PO}_{4}$ and water glass at each concentration. When the concentration of the inhibitor exceeds $25 \%$, the amount of the increasing rate slows itself 
down. When the concentration equals $35 \%$, the injection amount of the tonne of coal resistance agent becomes almost the same as the amount of the tonne coal inhibitor injection with a concentration of $25 \%$. The curve of the injection amount of tonne coal of $\mathrm{NH}_{4} \mathrm{H}_{2} \mathrm{PO}_{4}$ and water glass firstly increase and then decrease with the largest amount of tons of coal resistance agent injection, respectively $3.40 \mathrm{~kg}$ and $2.90 \mathrm{~kg}$ at a concentration of $25 \%$.

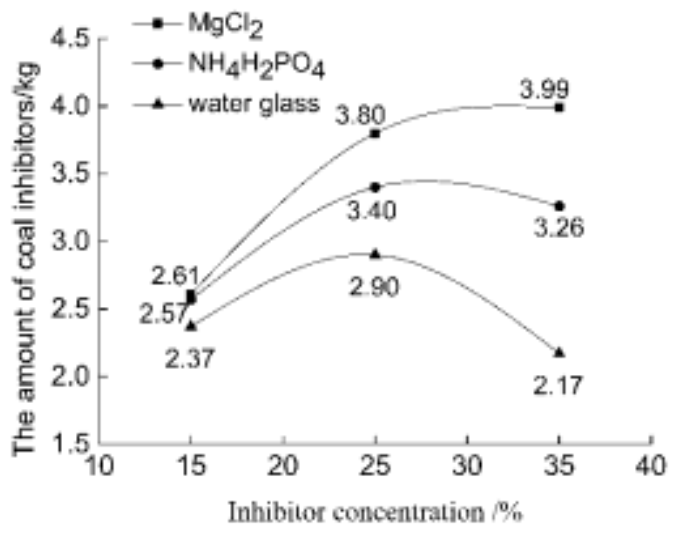

Fig. 2. The injection amount of coal inhibitors

\section{CONCLUSION}

(1) According to the pressurized water absorption, the average moisture increase is related to the variety and concentration of inhibitors. The average moisture increase of specimens in $\mathrm{MgCl}_{2}$ is the largest and declines with the increasing of the solution concentration.

(2) When the concentration is $15 \%$, it is easy for different inhibitors to be injected into the coal pore but the injection amounts of ton coal inhibition are not large and the effects of inhibition are not ensured. When the concentration is $25 \%$, the minimal aperture of pore that inhibitors are injected into coal in $\mathrm{MgCl}_{2}$ and $\mathrm{NH}_{4} \mathrm{H}_{2} \mathrm{PO}_{4}$ is from 0.08 to $0.10 \mu \mathrm{m}$ and the injection amounts are large and the effects are the best. When the concentration is $35 \%, \mathrm{NH}_{4} \mathrm{H}_{2} \mathrm{PO}_{4}$ and water glass are difficult to be injected into the coal pore.

(3) Considering the injection effects and costs, $\mathrm{MgCl}_{2}$ that the concentration is $25 \%$ can be selected to the advanced inhibition for the 3 upper coal seam in Nantun mine.

\section{ACKNOWLEDGMENT}

In this paper, the research was sponsored bythe National Key Research and Development Program of China (2016YFC0801703, 2017YFC0805207), the Key Research and Development Program of Shandong Province ( 2018GSF120016 , 2018GGX109004 ) , the Nature Science of Shandong Province (ZR2015PE005) and Shandong University of Science and Technology Scientific Research Fund Project of Talent Introduction (2015RCJJ038).

\section{REFERENCES}

[1] Li Jinliang, Lu Wei, Wang Zhenghui, et al. Analysis on Inhibition Mechanism of Preventing Spontaneous Ccombustion of Coal [J]. Mining Safety \& Environmental Protection, 2012, 39(02): 71-76.

[2] Niu Guoxiu, Yao Jian, Kang Huaiyu, et al. Test Research on Preventing Spontaneous Combustion in Gob with Pre-injecting Inhibitor into Coal[J]. Coal Mining Technology, 2009, 14(01): 25-28.
[3] Debasis Rath. Application of inhibitor to prevent to spontaneous heating of coal[D]. Rourkela : National Institute of Technology, 2012:38-47.

[4] He Fei, Wang Jiren, Hao Chaoyu, et al. Experimental Study on the effect of Oxygen Consuming Inhibitor in Inhabiting Coal Spontaneous Combustion[J]. Journal of China Coal Society, 2016, 41(11): 2780-2785.

[5] Wang Xuefeng, Deng Hanzhong, Deng Cunbao, et al. Research on Selection of Coal Spontaneous Combustion Inhibitor and Spraying Process [J]. China Safety Science Journal, 2013, 23(10): 105-109.

[6] Shan Yafei, Wang Jiren, Deng Cunbao, et al. Study on Influence of Different Inhibitors on Coal Spontaneous Combustion[J]. Journal of Liaoning Technical University (Natural Science). 2008, (01): 1-4.

[7] Zhou Xihua, Li Chengyu, Li Ang, et al. Research on Optimum Selection of Coal Spontaneous Combustion Inhibitors with Variation in Ignition Activation Energy as Index[J]. China Safety Science Journal, 2014, 24(06): 20-25.

[8] Ma Li, Ren Lifeng, Ai Shaowu, et al. Experimental Study on the Impact of the Chloride Inhibitor upon the Limited Parameters of the Coal Spontaneous Combustion[J]. Journal of Safety and Environment, 2015, 15(04): 83-88.

[9] Wang Hui, Zhao Wenjuan. Dynamic Optimization Research on the Minimum Thickness of $\mathrm{G}$ routing Layer for Blocking Water in Galongla Tunnel[J]. Journal of Shandong University of Science and Technology (Natural Science),2014,33(05):83-89.

[10] Gao Huanfu, Wang Ziliang. Research on Dust Generation Capacity and Injectability of Coal Seam in Wobei Mine[J]. Mining Safety \& Environmental Protection, 2012, 39 (10): 39-42.

[11] Qin Wengui, Zhang Yansong. Relation of Pore Distribution of Coal with Water Infusion Increment in Seams[J]. Journal of China Coal Society, 2000, (05): 514-517.

[12] Chen Kai, Jiang Zhenquan, Jiang Chunlu, et al. Experiment on Groutability and Grouting Reduced Infiltration Effect of Chemical Grout in Weak Cementation Porous Media[J]. Coal Safety, 2012, 43(06): 13-16

[13] Li Xiaolong, Wu Zhiming, Jiang Zhenquan, et al. Application of New Sol Resin Grout in Pore and Micro Fissures-rock Management[J] . Coal Safety, 2012, 43(07): 140-142.

[14] Ruan Wenjun. Research on Diffusion of Grouting and Basic Properties of Grouts[J]. Chinese Journal of Geotechnical Engineering, 2005, (01): 69-73

[15] Luo Pingping, He Shan, Zhang Wei. Present Situation of Study on Grouting Theories in Rock Masses and Its Prospect[J]. Journal of Shandong University of Science and Technology (Natural Science),2005,30(01):46-48. 